Antônio Augusto M. da Silva 1 Liberata Campos Coimbra 2 Raimundo Antônio da Silva 1 Maria Teresa S. S. de B. e Alves ${ }^{1}$ Fernando Lamy Filho 3 Zeni Carvalho Lamy 4 Elba Gomide Mochel 2 Vânia Maria de F. Aragão 3 Valdinar Sousa Ribeiro 3 Sueli Rosina Tonial 1 Marco Antônio Barbieri 5

\section{Perinatal health and mother-child health care in the municipality of São Luís, Maranhão State, Brazil}

\author{
Saúde perinatal e atenção à saúde \\ da mãe e da criança no Município de São Luís, \\ Maranhão, Brasil
}

1 Departamento de Saúde Pública, Universidade Federal do Maranhão. Rua Barão de Itapary 155, São Luís, MA 65020-070, Brasil.

2 Departamento de Enfermagem, Universidade Federal do Maranhão. Rua Viana Vaz s/n, São Luís, MA 65020-660, Brasil.

3 Departamento de Medicina III, Universidade Federal do Maranhão. Rua dos Prazeres 215, 50 andar (cobertura), São Luís, MA 65020-460, Brasil.

4 Hospital Universitário, Universidade Federal do Maranhão. Rua dos Prazeres 215, São Luís, MA 65020-460, Brasil.

5 Departamento de Puericultura e Pediatria, Faculdade de Medicina de Ribeirão Preto, Universidade de São Paulo. Av. Bandei rantes 3900 Ribeirão Preto, SP 14049-900, Brasil.
Abstract The purpose of this articlewas to evaluate soci oeconomic and demographic indicators, reproductive health, use of prenatal, childbirth, and neonatal services, and anthropometric data for mothers and infants. The authors performed a cross-sectional analysis of a systematic sample of 2,831 hospital births in São Luís, Maranhão State, from March 1997 to February 1998 at ten public and private maternity hospitals. The sample was stratified proportionally according to the number of births in each maternity hospital. Mothers answered a standard questionnaire. Of the total, $97.9 \%$ were live births and $98 \%$ were singl etons. Prenatal coverage was $89.5 \%$, and prevalence of cesarean sections was 33.8\%. A physician provided prenatal care in $75.7 \%$ of cases and performed $73.8 \%$ of the deliveries. The Unified Health System covered the costs of $76.4 \%$ of the prenatal visits and $89.7 \%$ of the deliveries. A pediatrician was present in the delivery room in $50.2 \%$ of cases. The low birth weight rate was $9.6 \%$ and the preterm birth rate $13.9 \%$. Reasons for concern included a high percentage of adolescent mothers, single mothers (or without partners), the high cesarean rate, and the high percentage of births attended by unqualified personnel.

Key words Low Birth Weight; Premature; Fetal Growth Retardation; Prenatal Care; Cesarean Section

Resumo Este artigo teve o objetivo de estimar indicadores sóci o-econômi cos, demográficos, saúde reprodutiva, utilização de servi ços pré-natais e de atenção ao parto e ao recém-nasci do, dados antropométricos da mãe e da criança. Foi realizado estudo transversal em amostra sistemática de 2.831 nascimentos hospitalares ocorri dos em São Luís, estratificada por maternidades, com partilha proporcional ao número de nascimentos em cada unidade, no período de março de 1997 a fevereiro de 1998. Utilizou-se questionário padronizado respondido pela puérpera. Analisaram-se nascimentos em dez unidades de saúde, públicas e privadas, dos quais, $97,9 \%$, eram nascidos vivos e $98 \%$ de parto único. A cobertura do pré-natal foi de $89,5 \%$. A prevalência de cesarianas 33,8\%. O médi co realizou 75,7\% do atendimento pré natal e 73,5\% dos partos. O Sistema Único de Saúde custeou 76,4\% do atendimento prénnatal e $89,7 \%$ da assistência ao parto. O atendimento por pediatra em sala de parto foi de 50,2\%. A taxa de baixo peso ao nascer foi de $9,6 \%$ ede prematuridade $13,9 \%$. Alta porcentagem de mães adolescentes e sem companhei ro, al ta taxa de cesáreas e de partos assisti dos por pessoal não qualificado, são razões para preocupação.

Palavras-chave Baixo Peso ao Nascer; Prematuro; Retardo do Crescimento Fetal; Cui dado PréNatal; Cesárea 
Introduction

Mother-child health problems have been approached by several epidemiological studies in Brazil (Barbieri et al., 1989; Barros et al., 1996; Bettiol et al., 1998; Victora et al., 1996), but in the State of Maranhão the few available studies have failed to use a sufficiently systematic approach, and few investigations have been conducted on representative samples of different municipalities or counties (Coimbra et al., 1996; Estado do Maranhão/U NICEF, 1992; Silva et al., 1999; Tonial \& Silva, 1997). Few studies are available assessing the coverage and quality of health care services (Estado do Maranhão/UNICEF, 1992; Silva et al., 1999).

Knowledge is insufficient on rates of pregnancy outcomes such as low birth weight, preterm birth, and intrauterine growth retardation in Brazil. Registry sources are generally unreliable. Specifically, the SINASC (National Live Birth Information System) lacks sufficient coverage in some places to allow valid estimates. In addition, perinatal mortality rates are unknown for most settings due to lack of proper records, especially concerning stillbirths.

Lack of reliable information for motherchild health indicators hinders the planning and evaluation of measures to improve living standards. It is thus extremely important to perform surveys to evaluate heal th conditions and the use of preventive and curative services.

We thus undertook the present cross-sectional survey based on a sample of hospital births in maternity hospitals in the municipality of São Luís from March 1997 to February 1998 in order to assess maternal and perinatal health conditions in this city.

\section{Methodology}

The study used the same methodology as two other perinatal studies, conducted in Ribeirão Preto, São Paulo State, in 1978-79 and 1994 (Barbieri et al., 1989; Bettiol et al., 1998; Gomes et al., 1999; Silva et al., 1998) as part of a multicenter project on perinatal health in Brazilian cities.

The municipality of São Luís is located on the island of São Luís in the northern part of the State of M aranhão and has an area of $518 \mathrm{~km}^{2}$. Total population is 781,068 (IBGE, 1997). Prenatal care is provided by 35 municipal health units, 7 State units, and 1 Federal unit, as well as by health services contracted out by the Unified Health System (SUS) and private units. Childbirth care is provided by 18 public and private maternity services.
Sampling

The study used a cross-sectional approach. We used a sample of hospital births in São Luís, including mothers residing in the city, non-residents, live births, stillbirths, singletons, and multiple births. Hospital births represented $96.3 \%$ (95\% Cl: 94.1-98.6) of all births in 1996, thus ensuring that the hospital birth sample is representative (Tonial \& Silva, 1997). The study was conducted at 10 units consisting of public, contracted-out, and/ or private facilities from March 1, 1997, to February 28, 1998. Maternity services where less than 100 deliveries were performed in 1996, i.e., only $2.2 \%$ of the deliveries that occurred during that year, were excluded from the study.

The sample was stratified proportionally according to the number of deliveries in each maternity hospital. All births in each unit were listed in order of occurrence. Systematic sampling was performed in each unit, with a sampling interval of seven. A random number between 1 and 7 was picked to determine the starting point for each study unit.

Calculation of sample size for the estimate of a proportion considering the population size of 20,092 births for the year preceding the study, with $2 \%$ precision, $5 \%$ type I error, and working with a maximum pxq product $(50 \%$ event proportion) demonstrated that 2,145 interviews were necessary. Since the study al so aimed to compare proportions considering a $5 \%$ type I error and $80 \%$ study power, working with a maximum pxq product ( $50 \%$ event proportion) and setting the minimum difference to be detected as significant at $4 \%$, the minimum sample size was calculated at 2,499 births. Considering study losses, we opted to work with a sampling interval of seven, which would permit a sample size of approximately 2,870 births (Kalton, 1983).

\section{Instruments}

We worked with three research instruments: Birth and Interview Recording Card, Standardized Questionnaire, and Mortality Investigation Card. Information concerning all births in order of occurrence, all interviews performed, and cases of refusal to respond to the questionnaire or mother's discharge before the interview was recorded on the birth and interview card. The data recorded on this control card were birth date and mother's name and whether the infant was live-born or still born. In the case of multiple births the mother was recorded on two or more cards. In cases of early discharge, 
the mother was interviewed at home if she resided in the municipality of São Luís. Losses due to refusal or inability to locate the mother occurred in $5.8 \%$ of cases.

Variables included in the questionnaire are described below.

Questions concerning identification were: questionnaire number, name of hospital, name of child and mother, address, reference point, neighborhood, city and State, and area of residence (urban or rural).

The following demographic and socioeconomic data were studied: whether mother and father lived in the home, number of siblings and number of persons residing in the household, maternal and paternal educational level, family and per capita income in minimum wages, mother working outside the home, and occupation of the head of the family (considered to be the person with the highest income), housing conditions, and presence of running water and sewage disposal. The occupation of the head of family was used for socioeconomic classification based on the International Classification of Occupations (ISCO) (Silva et al., 1998).

Data concerning reproductive health were birth date of the infant's mother, age of the infant's father, number of pregnancies, parity, number of live-borns and stillborns, number of abortions, and number of low birth weight newborns. All previous pregnancies and the current one were defined in terms of date of termination, length of gestation, and age of fetal or neonatal death when applicable.

Information was obtained about smoking, whether the mother smoked, at what age she started smoking, for how many years she had been smoking, what she smoked (cigarettes, cigars, or pipe), and number of times the mother smoked per day before and during pregnancy. The questionnaire also asked whether the father was currently smoking, what he smoked, and how many times a day he smoked during the mother's respective gestation.

Concerning utilization of prenatal services, the mother was asked about prenatal care, the month she had started, number of visits, and tetanus immunization. The mother was also asked whether she had health insurance and which category of prenatal care she had received (government health coverage, private health plan, or out-of-pocket). Date of last menstrual period and gestational length in weeks were recorded, and the occurrence of prenatal diseases was investigated. With respect to utilization of childbirth care services, we recorded the number of fetuses, who provided care at delivery, type of delivery, category of care, and (in the case of maternal death) date of death and primary and associated causes.

Adequacy of prenatal care utilization was measured using the index of the same name (APNCU) (Kotelchuck, 1994) and by a new index created on the basis of the minimum number of scheduled visits as recommended by the Brazilian Health Ministry and timing of initiation (Coimbra, 1999). Both indices are adjusted on the basis of total gestational length, considering that mothers of premature infants tend to have fewer prenatal visits.

Gestational age was calculated from the date of the last normal menstrual period reported by the mother. At first, the 15th of the month was considered for all cases in which only the day (not month) of the last menstruation was unknown. Cases of weight incompatible with date of last menstrual period reported and located above the 99th percentile for the English curve were recorded as unknown (Altman \& Coles, 1980). The same procedure was used for cases of improbable gestational age (less than $\mathbf{2 0}$ or more than 50 weeks). Finally, a process of imputation was carried out for all cases of missing data or data recorded as ignored in a regression model including birth weight, parity, family income, and sex of the newborn (Stata Corporation, 1997).

Classification of weight by gestational age was based on the Williams curve (Williams et al., 1982). Infants were considered to be large for gestational age when their weight was above the 90th percentile for this curve, adequate for gestational age when their weight was between the 10th and 90th percentile, and small for gestational age when their weight was below the 10th percentile, the latter representing cases of intrauterine growth retardation.

With respect to the newborn, we recorded sex, live-born or stillborn status, birth date, neonatal diseases and, in case of fetal or neonatal death, the date and time of death as well as the primary and associated causes.

A mortality study of this birth cohort is currently under way, identifying fetal deaths and infant deaths (under one year of age) in the five Civil Registry Offices in the municipality. Death certificates are being copied, hospital records of these deaths are being analyzed, and in some cases interviews are conducted with physicians, mothers, and/ or other family members for a more precise definition of the primary cause of death. 
Anthropometric data

Birth weight was measured using infant scales adjusted to 10 grams. The infant was weighed shortly after birth without clothes. Scales used in the hospitals were verified periodically and replaced whenever defects were detected. Newborns were measured at between 12 and 24 hours of life using an ARTHAG-type anthropometer. Mother's height was determined with a UNICEF (United Nations Children's Fund) portable wall anthropometer, and arm girth was measured with a standard tape measure. The mother was asked to report her weight at the beginning and end of pregnancy.

\section{Statistical analysis}

In the present paper we report the calculation of percentages for the major indicators investigated and some of their respective $95 \%$ confidence intervals.

\section{Results}

A total of 2,831 births were analyzed, including live-borns and stillborns and single and multiple births. Most deliveries (84.9\%) occurred in the 4 largest hospitals (public or contracted out by the SUS); $89.8 \%$ of deliveries involved families residing in the municipality of São Luís, and $90.1 \%$ involved families from the greater metropolitan area.

Socioeconomic and demographic characteristics of families are listed in Table 1 . Most families (52.7\%) had an income of less than 3 times the minimum wage, and most heads of families (71\%) were semi-skilled or unskilled hand laborers; $24.2 \%$ of the mothers also worked outside the home. Most households (61.1\%) contained 5 or more members.

The highest percentage of mothers had 5 to 8 years of schooling (42.2\%), nearly $30 \%$ were under 20 years of age, and $13.4 \%$ were under 18. Nearly half (47.2\%) were in common-law marriages, and $24.4 \%$ had no partner. Most were having their first child (47.8\%). Smoking prevalence among women in this population group was low, only 5.9\%. Among smokers, $65 \%$ smoked up to 10 cigarettes per day during pregnancy, considered a low figure. Prevalence of previous stillbirth(s) was 3.1\%, and prevalence of prior abortion was $20.8 \%$. Prior low birth weight was reported by $7.8 \%$ of mothers (Table 2).

Prenatal care coverage was $89.5 \%$, but the use of prenatal care is still not universal. Ap- proximately $25 \%$ of mothers had fewer than 4 prenatal visits, but more than half (54.9\%) started prenatal care during the first trimester of pregnancy. More than $75 \%$ of prenatal care was covered by the SUS. According to the APNCU index, only $13 \%$ of the pregnant women had received adequate prenatal care. However, according to the new index, nearly half the pregnant women had received adequate care (Table 3).

Approximately $75 \%$ of the women received prenatal care exclusively from a physician, while $10.8 \%$ received care solely from nurses. Multiprofessional prenatal care was observed in $13.5 \%$ of cases. Most women (84.1\%) showed adequate tetanus immunization, adding those who received 2 or 3 doses of vaccines and those who had been previously immunized. Blood tests for detection of syphilis were ordered in $77.7 \%$ of cases, and blood typing was performed in $87.5 \%$.

The cesarean rate was $33.8 \%(95 \% \mathrm{Cl}: 32.0-$ $35,5)$. Although all births occurred in the hospital, only $73.5 \%$ were performed by physicians, demonstrating that a significant proportion of patients (19\%) received care from nursing attendants. SUS covered nearly $90 \%$ of the deliveries. According to the records, $10.1 \%$ of women received tubal ligations in association with the cesarean section (Table 4). Thus, tubal ligation was performed in $29.8 \%$ of the cesarean deliveries. Considering primary and repeat cesarean deliveries separately, tubal ligation was performed in $16.7 \%$ and $57.1 \%$ of cases, respectively. Only $12.6 \%$ of the women were accompanied by the same health care professional during the prenatal period and at delivery.

Some characteristics of the newborns and care provided can be seen in Table 5. Of all births, 55\% were males. The low birth weight rate was $9.6 \%(95 \% \mathrm{Cl}: 8.5-10.7)$ and the preterm birth rate was $13.9 \%(95 \% \mathrm{Cl}: 12.7-15.2)$. Intrauterine growth retardation was observed in $14.6 \%$ of cases (95\% Cl: 13.3-15.9). Mean birth weight was 3,142 grams.

Only $50.2 \%$ of the newborns were accompanied by a pediatrician in the delivery room, and rooming-in is still not universal, since $11.4 \%$ of the infants were transferred to a collective nursery. Most infants (76.3\%) had already started breastfeeding and $47.9 \%$ were assessed by the Apgar score. Fewer infants (35.3\%) were submitted to evaluation of gestational age by the Capurro method. 
Socioeconomic and demographic characteristics of families. São Luís, Maranhão State, Brazil, 1997/1998.

\begin{tabular}{|c|c|c|}
\hline Variables & $f$ & $\%$ \\
\hline \multicolumn{3}{|l|}{ Family income (times minimum wage) } \\
\hline$\geq 1$ & 486 & 17.2 \\
\hline $1.1-1.9$ & 459 & 16.2 \\
\hline $2-2.9$ & 545 & 19.3 \\
\hline 3-4.9 & 464 & 16.4 \\
\hline 5-9.9 & 413 & 14.6 \\
\hline$\geq 10$ & 262 & 9.3 \\
\hline Unknown & 202 & 7.1 \\
\hline \multicolumn{3}{|c|}{ Per capita family income (times minimum wage) } \\
\hline$<0.25$ & 520 & 18.4 \\
\hline $0.25-0.49$ & 805 & 28.4 \\
\hline $0.50-0.99$ & 695 & 24.6 \\
\hline$\geq 1$ & 608 & 21.5 \\
\hline Unknown & 203 & 7.2 \\
\hline \multicolumn{3}{|l|}{ Occupation of head of family } \\
\hline Managers and upper level professionals & 255 & 9.0 \\
\hline Middle level administrators & 313 & 11.1 \\
\hline Skilled workers & 162 & 5.7 \\
\hline Semi-skilled workers & 1,075 & 38.0 \\
\hline Unskilled workers & 935 & 33.0 \\
\hline Unemployed & 17 & 0.6 \\
\hline Unknown & 74 & 2.6 \\
\hline \multicolumn{3}{|l|}{ Number of persons per household } \\
\hline $1-4$ & 1,100 & 38.9 \\
\hline$\geq 5$ & 1,729 & 61.1 \\
\hline \multicolumn{3}{|l|}{ Mother working outside the home } \\
\hline Yes & 684 & 24.2 \\
\hline No & 2,146 & 75.8 \\
\hline Total & 2,831 & 100.0 \\
\hline
\end{tabular}

\section{Discussion}

In the municipality of São Luís, $85 \%$ of all births occurred in the four large public or SUS-contracted maternity hospitals. Ten percent of deliveries in São Luís involved families not residing in the municipality, mostly from the three other municipalities on the island of São Luís which are part of Greater Metropolitan São Luís.

Socioeconomic indicators generally revealed births in a population of low monthly income, predominantly consisting of semiskilled or unskilled hand laborers, the typical reality of most capital cities in the Northeast region of Brazil. In addition, households with numerous members were common. Socioeconomic data showed that most mothers had intermediate schooling.
Among the most relevant indicators in the present survey was the high proportion of adolescent mothers, including many under 18 years of age. This was also reflected in the high proportion of primiparous mothers. Another outstanding indicator was the high percentage of mothers without a partner (24\%). Both teenage pregnancy and not living with the child's father have been described as risk factors for poor perinatal outcomes such as low birth weight and intrauterine growth retardation (Lekea-Karanika et al., 1999).

Another item that deserves comment was the low proportion of smokers in this population, and the low number of cigarettes smoked by those who did smoke. This fact may reflect the low mean income of the population studied or may be due to other reasons 
Births according to some maternal characteristics. São Luís, Maranhão State, Brazil, 1997/1998.

\begin{tabular}{|c|c|c|}
\hline Variables & $f$ & $\%$ \\
\hline \multicolumn{3}{|l|}{ Maternal schooling (years) } \\
\hline No schooling & 199 & 7.1 \\
\hline $1-4$ & 314 & 11.1 \\
\hline $5-8$ & 1,192 & 42.2 \\
\hline $9-11$ & 994 & 35.2 \\
\hline$\geq 12$ & 124 & 4.4 \\
\hline \multicolumn{3}{|l|}{ Maternal age (years) } \\
\hline$<18$ & 380 & 13.4 \\
\hline $18-19$ & 466 & 16.5 \\
\hline $20-24$ & 1,072 & 37.9 \\
\hline $25-29$ & 548 & 19.4 \\
\hline $30-34$ & 235 & 8.3 \\
\hline $35-39$ & 104 & 3.7 \\
\hline$\geq 40$ & 24 & 0.9 \\
\hline \multicolumn{3}{|l|}{ Marital status } \\
\hline Married & 803 & 28.4 \\
\hline Cohabiting & 1,337 & 47.2 \\
\hline No partner & 639 & 22.6 \\
\hline Separated, widowed, divorced & 51 & 1.8 \\
\hline \multicolumn{3}{|l|}{ Parity } \\
\hline 1 & 1,353 & 47.8 \\
\hline 2 & 836 & 29.5 \\
\hline $3-4$ & 503 & 17.8 \\
\hline$\geq 5$ & 139 & 4.9 \\
\hline \multicolumn{3}{|l|}{ Maternal smoking } \\
\hline Yes & 166 & 5.9 \\
\hline No & 2,665 & 94.1 \\
\hline \multicolumn{3}{|l|}{ Previous stillbirth } \\
\hline Yes & 87 & 3.1 \\
\hline No & 2,744 & 96.9 \\
\hline \multicolumn{3}{|l|}{ Previous abortion } \\
\hline Yes & 588 & 20.8 \\
\hline No & 2,243 & 79.2 \\
\hline \multicolumn{3}{|l|}{ Previous low birth weight } \\
\hline Yes & 219 & 7.8 \\
\hline No & 2,591 & 92.2 \\
\hline Total & 2,831 & 100.0 \\
\hline
\end{tabular}

to be investigated in more detail in subsequent studies.

Prenatal coverage is good, but a significant percentage of mothers are still not covered, and quality of care is insufficient, with a significant proportion of precisely those pregnant women who are probably at greater perinatal risk still receiving no care. The adequacy index calculated on the basis of two indicators was low. The number of visits is insufficient and the proportion of patients who do not start prenatal care during the first trimester of pregnancy is high. Multiprofessional prenatal care is low. The three selected quality indicators also demonstrated that much is needed to improve prenatal care in the municipality. Only $12.6 \%$ of mothers were seen by the same professional during the prenatal period and at de- 
Prenatal care. São Luís, Maranhão State, Brazil, 1997/1998.

\begin{tabular}{|c|c|c|}
\hline Variables & $f$ & $\%$ \\
\hline \multicolumn{3}{|l|}{ Number of prenatal visits } \\
\hline 0 & 263 & 9.3 \\
\hline $1-3$ & 449 & 15.9 \\
\hline $4-5$ & 703 & 24.8 \\
\hline$\geq 6$ & 1,381 & 48.8 \\
\hline Unknown & 35 & 1.2 \\
\hline \multicolumn{3}{|c|}{ Trimester when prenatal care was started } \\
\hline No prenatal care & 263 & 9.3 \\
\hline First & 1,547 & 54.9 \\
\hline Second & 904 & 32.1 \\
\hline Third & 102 & 3.6 \\
\hline \multicolumn{3}{|l|}{ Category of prenatal care } \\
\hline No prenatal care & 263 & 9.3 \\
\hline Unified Health System (SUS) & 1,903 & 67.2 \\
\hline Contracted out by SUS & 259 & 9.2 \\
\hline Health insurance plan & 309 & 10.9 \\
\hline Out-of-pocket & 97 & 3.4 \\
\hline \multicolumn{3}{|c|}{ Professional who provided prenatal care } \\
\hline Physician & 1,945 & 75.7 \\
\hline Registered nurse & 276 & 10.8 \\
\hline Physician and registered nurse & 347 & 13.5 \\
\hline \multicolumn{3}{|c|}{ Kotelchuck's adequacy of prenatal care utilization index } \\
\hline Intensive & 84 & 3.0 \\
\hline Adequate & 282 & 10.0 \\
\hline Intermediate & 1,072 & 37.9 \\
\hline Inadequate & 1,393 & 49.1 \\
\hline \multicolumn{3}{|c|}{ Adequacy based on Health Ministry recommendations } \\
\hline Adequate & 1,403 & 49.6 \\
\hline Intermediate & 430 & 15.2 \\
\hline Inadequate & 998 & 35.3 \\
\hline Total & 2,831 & 100.0 \\
\hline
\end{tabular}

livery, although this is a widespread wish of mothers and an indicator of humanization of health care.

The cesarean rate was high and rising in the municipality (Estado do Maranhão/UNICEF, 1992). One of the probable causes of this cesarean rate is tubal ligation, performed together with nearly $30 \%$ of cesareans.

The persistence of a high percentage of hospital deliveries not assisted by qualified personnel (physician or registered nurse) is a phenomenon that must be evaluated in greater depth. The percentage of newborns examined by a pediatrician in the delivery room continues to be low despite a ruling by Ministry of Health instituting reimbursement for this pro- cedure (Brasil, 1993). It is necessary to determine by audit whether this payment is being made to professionals who are in fact failing to provide the service, since in many cases we detected neonatal medical records signed by a pediatrician, while in the questionnaire the mothers stated that no pediatrician was present in the delivery room.

Neonatal care still leaves much to be desired. Rooming-in for normal infants is not practiced in all cases. In some hospitals, infants had still not begun breastfeeding after 24 hours.

Comparison of some demographic and medical care characteristics reported in the three perinatal studies conducted in Brazil in the 1990s showed that Pelotas had the highest 
Delivery care. São Luís, Maranhão State, Brazil, 1997/1998.

\begin{tabular}{lcc}
\hline Variables & $f$ & $\%$ \\
\hline Type of delivery & 1,875 & 66.2 \\
$\quad$ Vaginal & 646 & 22.8 \\
Primary cesarean section & 310 & 11.0 \\
Repeat cesarean section & & \\
Tubal ligation during cesarean section & 285 & 10.1 \\
Yes & 2,546 & 89.9 \\
No & & \\
Professional who performed the delivery & 2,080 & 73.5 \\
Physician & 94 & 3.3 \\
Registered nurse & 537 & 19.0 \\
Nursing attendant & 98 & 3.5 \\
Midwife or health agent & 3 & 0.1 \\
Other & 19 & 0.7 \\
No information & & \\
Category of admission & 1,667 & 58.9 \\
Unified Health System (SUS) & 873 & 30.8 \\
Contracted out by SUS & 247 & 9.1 \\
Health insurance plan & 34 & 1.2 \\
Out-of-pocket & & 100.0 \\
Same professional providing prenatal and delivery care & 324 & \\
Yes & 2,244 & 2,831 \\
No & & \\
Total & & \\
\hline
\end{tabular}

percentage of families with an income of up to one minimum wage. The percentage of mothers without a partner was $12.3 \%$ in Pelotas, $11.4 \%$ in Ribeirão, and $24.4 \%$ in São Luís. Mothers under 20 years of age represented $17.4 \%$ of births in Pelotas, $17.5 \%$ in Ribeirão Preto, and 29.9\% in São Luís (Bettiol et al., 1998; Costa et al., 1996; Victora et al., 1996).

Another major difference was in the percentage of smoking mothers: 5.7\% in São Luís, 33.5\% in Pelotas, and $20.3 \%$ in Ribeirão Preto. Primiparae represented $35.1 \%$ of births in Pelotas, $36.8 \%$ in Ribeirão Preto, and $47.8 \%$ in São Luís (Bettiol et al., 1998; Tomasi et al., 1996).

While in Ribeirão Preto only $2.4 \%$ of mothers failed to receive prenatal care, this percentage was higher in Pelotas (4.9\%) and even higher in São Luís (9.3\%). The cesarean rate also varied among the three municipalities: $30.5 \%$ in Pelotas, $53.2 \%$ in Ribeirão Preto, and 33.8\% in São Luís. In Pelotas, $88.3 \%$ of the deliveries were attended by physicians, while the percentage was lower in São Luís (73.5\%). The SUS reimbursed the cost of $55.1 \%$ of deliveries in
Ribeirão and 89.7\% in São Luís (Costa et al., 1996; Silva et al., 1998; Victora et al., 1996).

Considering only singleton live births, the low birth weight rate was lower in São Luís (7.6\%) than in Pelotas (9.1\%) and Ribeirão Preto (10.6\%). A higher preterm birth rate was also observed in Ribeirão (14.8\%), while an intermediate rate was observed in São Luís (12.4\%) and a lower rate was observed in Pelotas (8.0\%) (data not shown). As observed in São Luís, most premature infants showed no low birth weight in Ribeirão Preto. In Pelotas this phenomenon does not appear to occur. São Luís presented a much higher prevalence of intrauterine growth retardation than Pelotas (Silva et al., 1998; Victora et al., 1996).

Prevalence of low birth weight and preterm birth was approximately the same as described for the entire United States population in recent years (NCHS, 1999), an intriguing fact if we consider that the known risk factors for low birth weight are much more prevalent in the São Luís population.

Similarly, comparison of the statistical data with those of other Brazilian cities (Pelotas and 
Table 5

Characteristics of newborns and type of care provided to them.

São Luís, Maranhão State, Brazil, 1997/1998.

\begin{tabular}{|c|c|c|}
\hline Variables & $f$ & $\%$ \\
\hline \multicolumn{3}{|l|}{ Low birth weight } \\
\hline Yes & 270 & 9.6 \\
\hline No & 2,548 & 90.4 \\
\hline \multicolumn{3}{|l|}{ Preterm birth } \\
\hline Yes & 394 & 13.9 \\
\hline No & 2,437 & 86.1 \\
\hline \multicolumn{3}{|c|}{ Weight for gestational age classification } \\
\hline Small & 411 & 14.6 \\
\hline Adequate & 2,195 & 77.9 \\
\hline Large & 212 & 7.5 \\
\hline \multicolumn{3}{|c|}{ Professional assisting newborn } \\
\hline Pediatrician & 1,420 & 50.2 \\
\hline Obstetrician & 32 & 1.1 \\
\hline Anesthesiologist & 6 & 0.2 \\
\hline Registered nurse & 204 & 7.2 \\
\hline Nursing attendant & 946 & 33.4 \\
\hline Midwife & 33 & 1.2 \\
\hline Other & 5 & 0.2 \\
\hline No information & 185 & 6.2 \\
\hline \multicolumn{3}{|c|}{ Type of lodging for newborn } \\
\hline Bedside cradle & 1,304 & 46.1 \\
\hline Collective nursery & 324 & 11.4 \\
\hline Intermediate nursery & 351 & 12.4 \\
\hline In bed with the mother & 736 & 26.0 \\
\hline Intensive care unit & 56 & 2.0 \\
\hline NA & 60 & 2.2 \\
\hline \multicolumn{3}{|c|}{ Beginning of breastfeeding in the first 24 hours of life } \\
\hline Yes & 2,160 & 76.3 \\
\hline No & 480 & 17.0 \\
\hline No information & 191 & 6.7 \\
\hline \multicolumn{3}{|l|}{ Apgar measured } \\
\hline Yes & 1,355 & 47.9 \\
\hline No & 1,365 & 48.2 \\
\hline No information & 111 & 3.9 \\
\hline \multicolumn{3}{|l|}{ Capurro measured } \\
\hline Yes & 1,000 & 35.3 \\
\hline No & 1,745 & 61.7 \\
\hline No information & 86 & 3.0 \\
\hline Total & 2,831 & 100.0 \\
\hline
\end{tabular}


Ribeirão Preto) leads us to ask the following questions: why did São Luís present the lowest low birth weight rate among the three towns? Why did Ribeirão Preto present the highest preterm birth rate among the three towns? Why did approximately $60 \%$ of the preterm infants fail to present low birth weight? These questions need to be answered by future research. Low prevalence of maternal smoking may be one of the reasons for the lower than expected low birth weight rate detected by our study.

\section{Acknowledgements}

We wish to thank the mothers of São Luís, the staff and administrators of the maternity hospitals, and students interns who obtained the anthropometric data and conducted the interviews. We are also grateful to Nilza Nunes da Silva from the Department of Epidemiology, School of Public Health, University of São Paulo, who assisted us in drawing sampling procedures. We wish to express our thanks to the Brazilian National Research Council (CNPq) for funding this study, under grant 523474/ 96-2.

\section{References}

ALTMAN, D. G. \& COLES, E. G., 1980. Nomograms for precise determination of birth weight for dates. British Journal of Obstetrics and Gynaecology, 87: 81-86.

BARBIERI, M. A.; GOMES, U. A.; BARROS FILHO, A. A.; BETTIOL, H.; ALMEIDA, L. E. A. \& SILVA, A. A. M., 1989. Saúde perinatal em Ribeirão Preto, SP, Brasil: A questão do método. Cadernos de Saúde Pública, 5:376-387.

BARROS, F. C.; VICTORA, C. G.; TOMASI, E.; HORTA, B.; MENEZES, A. M.; CESAR, J. A.; HALPERN, R.; OLINTO, M. T.; POST, C. L.; COSTA, J. S. D.; MENEZES, F. S.; GARCIA, M. M. \&VAUGHAN, J. P., 1996. Saúde materno-infantil em Pelotas, Rio Grande do Sul, Brasil: Principais conclusões da comparação dos estudos das coortes de 19821993. Cadernos deSaúdePública, 12(Sup. 1):87-92.

BETTIOL, H.; BARBIERI, M. A.; GOMES, U. A.; ANDREA, M.; GOLDANI, M. Z. \& RIBEIRO, E. R. O., 1998. Saúde perinatal em Ribeirão Preto, SP, Brasil, 1994: Metodologia e algumas características da população estudada. Revista deSaúdePública, 32:18-28.

BRASIL, 1993. Portaria no 31 de 15 de fevereiro de 1993. Brasília: Diário Oficial da União, vol. 33, no 2, p. 2111.17 feb. 
COIMBRA, L. C., 1999. Adequação do Uso da Assistência Pré-Natal em São Luís - Maranhão. Dissertação de Mestrado, São Luís: Mestrado em Saúde e Ambiente, Universidade Federal do Maranhão.

COIMBRA, L. C.; SOARES, M. C.; PAIVA, M. F. L. \& MARTINS, M. G. P., 1996. Morbidade referida e utilização dos serviços de saúde no município de São Benedito do Rio Preto - Maranhão, 1995. Revista Brasileira de Enfermagem, 49:519-530.

COSTA, J. S. D.; VICTORA, C. G.; BARROS, F. C.; HALPERN, R.; HORTA, B. L. \& MANZOLLI, P., 1996. Assistência médica materno-infantil em duas coortes de base populacional no Sul do Brasil: Tendências e diferenciais. Cadernos de Saúde Pública, 12(Sup. 1):59-66.

ESTADO DO MARANHÃO/UNICEF (United Nations Children's Fund), 1992. Crianças e Adolescentes no Maranhão: Saúde, Educação eTrabalho. São Luís: Governo do Estado do Maranhão/UNICEF.

GOMES, U. A.; SILVA, A. A. M.; BETTIOL, H. \& BARBIERI, M. A., 1999. Risk factors for the increasing caesarean section rate in Southeast Brazil: A comparison of two birth cohorts, 1978/79 and 1994. International Journal of Epidemiology, 28:687694.

IBGE (Fundação Instituto Brasileiro de Geografia e Estatística), 1997. Contagem da População: Resultados Relativos a Sexo da População e Situação da Unidade Domiciliar, 1996. Rio de Janeiro: IBGE.

KALTON, G., 1983. Introduction to Survey Sampling. Beverly Hills: Sage Publications.

KOTELCHUCK, M., 1994. Evaluation of the Kessner adequacy of prenatal care index and a proposed adequacy of prenatal care utilization index. American Journal of Public Health, 84:1414-1421.

LEKEA-KARANIKA, V.; TZOU MAKA-BAKOULA, C. \& MATSANIOTIS, N. S., 1999. Sociodemographic determinants of low birth weight in Greece: A population study. Paediatric and Perinatal Epidemiology, 13:65-77.
NCHS (National Center for Health Statistics), 1999. Preterm singleton births - United States, 19891996. MMWR, 48:185-189.

SILVA, A. A. M.; BARBIERI, M. A.; GOMES, U. A. \& BETTIOL, H., 1998. Trends in low birth weight: A comparison of two birth cohorts separated by a 15 year interval in Ribeirão Preto, Brazil. Bulletin of theWorld Health Organization, 76:73-84.

SILVA, A. A. M.; GOMES, U. A.; TONIAL, S. R. \& SILVA, R. A., 1999. Cobertura vacinal e fatores de riscos associados à não vacinação em localidade urbana do Nordeste Brasileiro, 1994. Revista de Saúde Pública, 33:147-156.

STATA CORPORATION, 1997. Stata Reference Manual Rel ease 5. College Station: Stata Corporation.

TOMASI, E.; BARROS, F. C. \& VICTORA, C. G., 1996. As mães e suas gestações: Comparação de duas coortes de base populacional no Sul do Brasil. Cadernos de Saúde Pública, 12(Sup. 1):21-25.

TONIAL, S. R. \& SILVA, A. A. M. (org.), 1997. Saúde, Nutrição e Mortalidade Infantil no Maranhão. São Luís: Universidade Federal do Maranhão/ Secretaria de Estado da Saúde/United Nations Children's Fund.

VICTORA, C. G.; BARROS, F. C.; HALPERN, R.; MENEZES, A. M. B.; HORTA, B. L.; TOMASI , E.; WEIDERPASS, E.; CESAR, J. A.; OLINTO, M. T.; GUIMARÃES, P. R. V.; GARCIA, M. M. \&VAUGHAN, J. P., 1996. Estudo longitudinal da população materno-infantil da região urbana do Sul do Brasil 1993: Aspectos metodológicos e resultados preliminares. Revista de SaúdePública, 30:34-45.

WILLIAMS, R. L.; CREASY, R. K.; CUNNINGHAM, G.; HAWES, W. E.; NORRIS, F. K. \& TASHIRO, M., 1982. Fetal growth and perinatal viability in California. Obstetrics \& Gynecology, 59:624-632. 